\title{
MORPHOMETRIC ANALYSIS AND VIRULENCE OF ISOLATES OF Toxoplasma gondii RECOVERED FROM PREGNANT AND NEWBORN MICE IN GOIÂNIA-GO, BRAZIL
}

\section{ANÁLISE MORFOMÉTRICA E VIRULÊNCIA DE ISOLADOS DE Toxoplasma gondii ISOLADOS DE MULHERES GRÁVIDAS E RECÉM-NASCIDOS EM GOIÂNIA-GO, BRASIL}

Marcos Gontijo da Silva', Fuad Moares Ibrahim', Gustavo José Von Glehn dos Santos $^{1}$, Omar Franklin Molina ${ }^{2}$, João Bartholomeu Neto ${ }^{3}$, Erica Eugênio Lourenço Gontijo ${ }^{4}$, Ana Maria de Castro ${ }^{5}$.

\section{RESUMO}

Introdução: Estudos com Toxoplasma gondii em recém-nascidos são relevantes porque desencadeiam graves lesões nestes se não tratadas.

Objetivo: Realizar análises morfométricas de isolados de formas taquizoítas de Toxoplasma gondii, recuperados de exsudados peritoneal em camundongos infectados com material biológico de gestantes e recém-nascidos em Goiânia-GO.

Metodologia: Três isolados de Toxoplasma gondii de recém nascidos e a cepa $\mathrm{RH}$ foram avaliados quanto à patogenicidade e virulência em camundongos Balb- $C$ albinos. A suspensão de taquizoítos utilizada nos testes foi obtida através da punção ou lavagem da cavidade peritoneal de camundongos que apresentaram ascite. Cada amostra foi inoculada em grupos de quatro camundongos, com inóculo de 101, 10², $10^{3}, 104,105$ e 106 taquizoítos vivos, via intraperitoneal.

Resultados e discussão: $O$ isolado-15, 20 e cepa $\mathrm{RH}$ foram letais a todos os camundongos. $\mathrm{O}$ isolado-3 foi letal a todos os camundongos até $10^{5}$ taquizoítos. A morte dos animais que apresentaram infecção aguda ocorreu entre 5 e 10 dias após a inoculação. O isolado-15, 20 e cepa $\mathrm{RH}$ apresentaram diâmetro maior e área menores que o isolado-3. Foi observado que 0 isolado mais virulento também apresentava diâmetro e área maior o que reforça a hipótese que além das diferenças de comportamento e variações genéticas, existam também variações morfológicas entre as diferentes cepas de $T$. gondii.

Considerações finais: Este novo parâmetro morfométricos corrobora para a presença de diversidade entre cepas isoladas e pode constituir uma nova informação usada para caracterizar e analisar essas cepas.

Descritores: Toxoplasma gondii; Isolar; Recémnascido.

\section{ABSTRACT}

Introduction: Studies in Toxoplasma gondii performed in newborns are interesting and relevant because they induce serious injuries in newborns when they are not properly treated.

Objective: To perform morphometric analyses of Toxoplasma gondii isolated (Tachizoite forms), recovered from peritoneal exudation in mice infected with biological material recovered from pregnant women and newborns in Goiânia-GO.

Methodology: Three isolates of Toxoplasma gondii in newborns and the $\mathrm{RH}$ lineage were evaluated as to the pathogenicity and virulence in Balb-c albino mice. The suspension of Taquizoito used in experimental tests was obtained by puncture or washing of the peritoneal cavity in mice with ascites. Each sample was inoculated into groups of four mice with inoculators of 10, 10, $10,10,10,10$ taquizoitos living, via intra peritoneum.

Results and discussion: It was discovered that the isolates 15, 20 and $\mathrm{RH}$ lineage were lethal in mice. The isolate- 3 behaved lethally in all mice up to 10 taquizoítos. The death of all animals that presented acute infection occurred 5-10 days after inoculation. Insulated-15, insulated-20 and $\mathrm{RH}$ strains showed greater diameter and smaller areas compared to the insulated-3. It turned out that the most virulent isolate also demonstrated greater area and diameter, and these findings reinforce the hypothesis that, in addition to behavioral differences and genetic variations, there are also morphological variations when different strains of T. gondii are evaluated.

Final considerations: This new morphometric parameter corroborates the presence of diversity between isolated strains and may constitute new information used to characterize and analyze these strains.

Descriptors: Toxoplasma gondii; Isolate; Newborn.
Associate Professor of the Medicine course at the University Center UNIRG. Doctor in Tropical Medicine and Public Health E-mail: gontijobio@yahoo.com.br

MAILING ADDRESS:

Av. Pará, block 20, lot $01 \mathrm{n}^{0}$ 2432 - Bairro Engenheiro Waldir Lins II, Gurupi - TO, Brazil.

Phone: (63) 98126-9197. 
10.18606/2318-1419/amazonia.sci.health.v6n1p48-53 Revista Amazônia Science \& Health.

2018 Jan/Mar
Silva MG, Ibrahim FM, Santos GJVG, Molina OF, Neto JB, Gontijo EEL, Castro AM.

Morphometric analysis and virulence of isolates of Toxoplasma gondii recovered from pregnant and newborn mice in Goiânia-GO, Brazil.

\section{INTRODUCTION}

Toxoplasmosis is an infection caused by the protozoan Toxoplasma gondii, which is found in diverse clinical forms, among them, the congenital form which may cause a diversity of sign and symptoms in the fetus depending on gestational age in which infection occurred and/or on the intrinsic or extrinsic characteristic of the parasite ${ }^{1-4}$.

Samples of Toxoplasma gondii which have been isolated in humans, although apparently with a similar morphology, present biological, serological and immunological variations ${ }^{5-7}$. Differences in the antigenic profile of $T$. gondii have been described in isolated strains in a variety of hosts and also in intraspecific samples ${ }^{5-8}$. Major criteria to evaluate virulence of $T$. gondii strains are the percentages of mortality of mice infected with gradual inoculates of parasites as well as survival time of those that did not resist to that infection ${ }^{5,8}$. Along these lines, most T.gondii strains have been defined as virulent, non virulent or with intermediate virulence depending on the morbidity and mortality in infected mice with that bacteria ${ }^{4,7-9}$. The $\mathrm{RH}$ strain and those genetically similar strains, demonstrate a lethal dose of $100 \%$ (LD100) from only one viable parasite. On the other hand, non virulent strains demonstrate a higher LD100 or equal to 1000 parasites and chronic infections are experimentally produced easily in mice ${ }^{5}$.

The goal of this investigation was to observe morphometric difference of tachyzoite forms and biologic behavior of three isolates of $T$. gondii recovered from mice peritoneal exudate, correlating two techniques, as a method of characterization of the parasite recovered from pregnant and fetuses with the $\mathrm{RH}$ strain in experimentally infected mice.

The objective of the study was to carry out morphometric analysis of Toxoplasma gondii isolates (Tachizoite forms), recovered from peritoneal exudates in mice infected with biologic material recovered from pregnant and newborns in Goiânia-GO and to compare those isolates with the $\mathrm{RH}$ strain.

\section{METHODOLOGY}

During the period from September 2005 and January 2010, in the Clinics Hospital of HC-UFG, pregnant women were followed-up in such a hospital. Pregnant women were referred to prenatal care as their routine clinical and/or serological examinations were positive for toxoplasmosis compatible with acute infection (presence of IgM confirmed with the avidity test of IgG having low avidity and with new serology using ELISA test to confirm the serologic screening test for the presence of $\operatorname{lgM}$ and $\lg G$ in those patients which were previously serologically negative).
Those female patients were referred to the reference medical center to evaluate the vertical transmission of toxoplasmosis (In the HC-UFG and Mothers -Children Hospital) in order to carry out the diagnosis of fetal infection and in whom, using amniocentesis and cordocentesis amniotic fluid and fetal blood were collected, respectively.

Amniocentesis was carried out and guided using ultra-sound and between the twenty and thirtyeight gestational weeks. Following guided anatomic location of both placenta and fetus, the amniotic cavity was punctured using and $15 \mathrm{~cm}$ needle, then $20 \mathrm{~mL}$ of amniotic fluid was collected. Cordocentesis was also performed using ultra-sound guided procedure and carried out at the same time with the previously mentioned invasive surgical procedure. Once direct puncture of the umbilical cord was carried out, about $3 \mathrm{~mL}$ of blood was collected in this procedure. Material obtained using this procedure was sent to the IPTSP-UFG Protozoology Laboratory in order to be processed and evaluated.

Amniotic fluid, liquor and blood (in both fetuses and newborns) were centrifuged at 3000 rpm during ten minutes, and the sediment containing red cells was inoculated through the peritoneum using a $1 \mathrm{~mL}$ syringe in a group of three males, isogenic BALC-c, mice $(0.2 \mathrm{~mL}$ per animal) with $30 \mathrm{~g}$ (weight) and thirty days (age). Serology was used in the supernatant searching for $\lg G$ and $\lg M$ class antibodies using indirect immunofluorescence. 465 mice were used in the first part of the experiment and 450 in the second one, totaling 914 animals. All mice used in this investigation were obtained from the animal facility or animal room at IPTSP-UFG.

Animals were followed-up during sixty days and then were sacrificed using vertebral column displacement. Cerebral maceration through the peritoneum was carried out in a second group of mice. For each analyzed material, six mice were used, three for inoculation of the material from the patient and three for the second inoculate carried out following sixty days.

Evaluated isolates were collected from peripheral blood and amniotic fluid inoculates from seropositive pregnant females and from the peripheral blood from a newborn mice Balb-c. Following inoculation, mice presented with a variety of symptoms indicating toxoplasmosis infection, then, a peritoneal lavage was carried out obtaining the tachyzoite forms characteristics of the acute phase infection. Three isolates named isolate-3, isolate- 15 and isolate -20 were obtained.

Isolates were diluted in sterile PBS so as to carry out parasitemia curves with the amount of $10^{1}$, $10^{2} 10^{3}, 10^{4}, 10^{5}, 10^{6}$ parasites for each mouse. Male mice 30 days of age were allocated to four different subgroups for each inoculate and 24 animals were used in each isolate. Animals were followed up every day recording their physical aspect and mortality rate. The $\mathrm{RH}$ strain was used 
10.18606/2318-1419/amazonia.sci.health.v6n1p48-53 Revista Amazônia Science \& Health.

2018 Jan/Mar
Silva MG, Ibrahim FM, Santos GJVG, Molina OF, Neto JB, Gontijo EEL, Castro AM.

Morphometric analysis and virulence of isolates of Toxoplasma gondii recovered from pregnant and newborn mice in Goiânia-GO, Brazil. as a control group. In each group of animals both water and food were given abundantly using appropriate utensils. Virulence was measured using the direct relationship and mortality rate of animals in different inoculates.

Smears from the intra-peritoneal fluid from the three isolates were placed directly on plates. Smears were air dried, immersed and conserved in methanol during three minutes and stained using Giemsa stain procedure with the proportion of $1 \mathrm{ml}$ buffer solution $\mathrm{pH} 7,2$ versus 3 drops of stain during 30 minutes. The Tachyzoites forms were then photographed with 100x magnification and measured using a computerized software (Axio Vision-3.1). Three measurements were carried out in each parasite: dimension in the longitudinal direction, larger diameter (DMA), transverse direction, lesser diameter (DME) and total area of flat surface (A). In each group, 100 parasites were analyzed.

Once all measurements were carried out, statistical methods were used including ANOVA followed by the Tukey test. Those groups not demonstrating a normal distribution were analyzed using non parametric Kruskal-Wallis test followed by post hoc Dunn's test so as to evaluate for size differences when two isolates were compared and when these two isolates were also compared with the $\mathrm{RH}$ strain used as a comparison group.

\section{RESULTS AND DISCUSSION}

Regarding virulence of $T$. gondii strains, it was found that in isolate 3 , mice treated with inoculates of $10^{6}$ forms died in the fifth day post inoculate; those treated with $10^{5}$ form died in the sixth day, those treated with $10^{4}$ died in the eight day and those that received the $10^{3}$ form demonstrated $50 \%$ of mortality in the eight day and the rest of them survived. Mortality was not observed in those groups receiving the $10^{1}$ and $10^{2}$ forms when inoculates were assessed up to sixty days following inoculation.

In those groups inoculated with isolate-15, those mice treated with inoculates of $10^{6}$ and $10^{5}$ forms, died in the fifth day following inoculation, those inoculated with the $10^{4}$ form died up to the sixth day, those treated with the $10^{3}$ and $10^{2}$ forms died in the seventh day and those treated with the form $10^{1}$, died in the ninth day following treatment with the inoculate.

In those groups inoculated with isolate 20, mice treated with $10^{6}$ and $10^{5}$ forms died in the sixth day following inoculation, those treated with the forms $10^{5}$ and $10^{3}$ and $10^{2}$ died in the eighth day and those treated with the $10^{1}$ form, died following ten days after inoculation. Experiments carried out with the control strain demonstrated $100 \%$ mortality between days three and eight (See Table 1 for further details).

Table 1. Survival in days of mice inoculated with increasing concentrations or numbers of the Tachyzoite forms of T. gondii.

\begin{tabular}{c|c|c|c|c}
\hline \multirow{2}{*}{$\begin{array}{c}\text { Number of } \\
\text { Parasites }\end{array}$} & \multicolumn{3}{|c}{ Survival Days } & RH Strain \\
\cline { 2 - 5 } & Isolate-3 & Isolate-15 & Isolate-20 & 7 \\
$10^{1}$ & 60 & 9 & 8 & 6 \\
$10^{3}$ & 60 & 7 & 8 & 5 \\
$10^{4}$ & 60 & 7 & 8 & 4 \\
$10^{5}$ & 7 & 6 & 5 & 3 \\
$10^{6}$ & 5 & 5 & 5 & 8 \\
\hline
\end{tabular}

Studies carried out in different regions and hosts have provided strong support for the point of view that $T$. gondii isolates from Brazil are biologically and genetically different as compared with those in North America and Europe, and present strong genetic variations ${ }^{10}$.

Samples of $T$. gondii have been differentiated through pathogenicity, which represents the capacity of the agent once into the host, of producing a variety of sign and symptoms and by its virulence, which is the capacity of the invader of producing pathological and even lethal effects ${ }^{7}$.

T. gondii strains are considered as virulent when intra peritoneal inoculation of less than 100 tachyzoites leads to acute signs and symptoms in mice and causing their dead in approximately one week; non virulent, when inoculation of larger doses , for instance, $10^{3}$ or $10^{4}$ tachyzoites does not cause neither significant signs and symptoms nor cyst formation in the brain ${ }^{11}$.

In the current study, two isolates (15 and 20), demonstrated to be extremely virulent as they caused mice mortality during the bioassay, whereas isolated 3 didn't show such a lethal characteristic. Further, the time elapsed from the moment of inoculation up to the moment of mice dead (5-10 days), was very similar to the outcome observed in a previous investigation ${ }^{12}$. A strain virulence is usually defined based in the rate of mortality of infected mice and time elapsed between inoculation moment and dead of animals 9 . In those three isolates which resulted in an acute form of the disease, time elapsed between inoculation and animals dead, was inversely proportional to the number of tachyzoites in the inoculate. 
10.18606/2318-1419/amazonia.sci.health.v6n1p48-53 Revista Amazônia Science \& Health.

2018 Jan/Mar
Silva MG, Ibrahim FM, Santos GJVG, Molina OF, Neto JB, Gontijo EEL, Castro AM.

Morphometric analysis and virulence of isolates of Toxoplasma gondii recovered from pregnant and newborn mice in Goiânia-GO, Brazil.
A differential pathogenicity and virulence or variation of $T$. gondii isolates were confirmed in the current study by observing differences in mortality rates of mice treated with different yet known amounts of tachyzoites in each one of the isolates. Differences in pathogenicity and virulence are more apparent in those cases in which dead of mice is observed directly as it is seen in the acute stage of the disease, or in those cases in which infected mice survive for a longer period of time as it occurs in the chronic form of the disease ${ }^{7}$. Noteworthy to mention is the role of the minimal inoculate of 10 x103 tachyzoites that was able to kill mice from isolate 3 , which was considered the less virulent.

Isolates 15 and 20, demonstrated a virulence which was quite similar to that observed in the case of $\mathrm{RH}$ strain. Isolate 3 demonstrated less virulence as the mean time of mortality was longer, but the mortality rate was less when compared with that of $\mathrm{RH}$ strain. In the current study, T. gondii was isolated from three blood samples of newborns presenting with congenital toxoplasmosis gondii, an observation that concurs with many other reports in the current literature ${ }^{5}$.

Based on one research ${ }^{13}, T$. gondii virulence is closely dependent on many factors including the stage of the parasite that remains inoculated, the pathway of inoculation or infection, dosage, type of mice used experimentally and the parasite strain. The parasitemia curve of those isolates that were evaluated, demonstrated that two of such isolates were extremely virulent to mice, although one was able to become chronic (cystogenic) even when the inoculate was low level or had low intensity in terms of pathogenicity.

Variability in the behavior of the isolates in the current study provides support to the clinical spectrum of the congenital infection by $T$. gondii which varies from some apparent clinical alterations at birth associated with high mortality and morbidity before or following birth including the development of microcephaly, delayed intra uterine growth and development and hydrocephaly) to a subclinical infection with a potential risk for the development of corioretinitis and/or delayed clinical alterations later in life ${ }^{14-16}$. In other cases, toxoplasmosis becomes chronic and clinical manifestations are not observed.

A possible explanation for the variety of clinical manifestations is the existence of a great number of strains including three different lineages that although different, are strongly interrelated ${ }^{4,17}$. These lineages have been denominated as type I, II and III and present a variation of less than $2 \%$ in their genome ${ }^{17}$. There is a notable difference in mice lethality when the three lineages are compared: Type I lineage is characterized by an absolute lethal dose (LD100) with only one viable parasite, and for this reason it has been denominated as virulent lineage. On the other hand, lineages I and II are characterized by a lethal dose of $50 \%$ (LD50) when the inoculates are equal or greater than one thousand parasites, in which a chronic infection is easily evoked. These lineages have been denominated as non-virulent ${ }^{8,17}$.

There are many plausible explanations to better understand the population structure of $T$. gondii. First, the parasite can be transmitted among intermediate hosts, through carnivore and necrophagic habits and not necessarily through the sexual cycle of the definitive host ${ }^{18}$. Second, a number of non-fertilized macrogametes remain viable into the definitive host, thus, being capable of forming oocysts through parthogenesis ${ }^{19}$. Third, though probably uncommon, transmission may also occur among naturally and simultaneously infected felines by two different lineages of $T$. gondii ${ }^{20}$.

Table 2. Measurement variations in the tachyzoites forms of $T$. gondii in three isolates and RH strain, in mice Balb-C.

\begin{tabular}{cllll}
\hline Measurement & Isolate-3 & Isolate-15 & Isolate-20 & RH Strain \\
\hline DMA $\left(_{\mu} \mathrm{m}\right)$ & $4,86(3,24-6,23)_{\mu} \mathrm{m}$ & $3,90(3,33-4,47)_{\mu} \mathrm{m}$ & $3,69(2,95-4,43)_{\mu} \mathrm{m}$ & $3,93(3,33-453)_{\mu} \mathrm{m}$ \\
DME $\left({ }_{\mu} \mathrm{m}\right)$ & $1,73(1,17-2,39)_{\mu} \mathrm{m}$ & $2,00(1,51-2,00)_{\mu} \mathrm{m}$ & $1,62(1,11-2,29)_{\mu} \mathrm{m}$ & $1,70(1,27-2,31)_{\mu} \mathrm{m}$ \\
$\mathrm{A}\left({ }_{\mu} \mathrm{m}^{2}\right)$ & $7,51(4,24-13,0)_{\mu} \mathrm{m}^{2}$ & $4,00(2,9-7,34)_{\mu} \mathrm{m}^{2}$ & $1,62(1,11-2,29)_{\mu} \mathrm{m}^{2}$ & $5,70(3,66-9,30)_{\mu} \mathrm{m}^{2}$ \\
\hline
\end{tabular}

DMA: Larger Diameter, DME: Smallest diameter, A: Area. ANOVA with Tukey' post test $(p>0.001)$. KruskalWallis with Dunn's post test $p>0.001$ ).

Regarding isolates morphometry, it was found that isolate-3, demonstrated the measurements as follows: greater diameter: 4,86 $(3,24-6,23){ }_{\mu} \mathrm{m}$, lesser diameter with median $1,73(1,17-2,39)_{\mu} \mathrm{m}$; area with median $7,51(4,24-13,0){ }_{\mu} \mathrm{m}$.

Isolate-15 presented the greatest diameter, $3,9(3,33-4,47){ }_{\mu} \mathrm{m}$, lesser diameter with median 2 $(1,51-2,00)_{\mu} \mathrm{m}$, area with median $4(2,9-7,34)_{\mu} \mathrm{m}$.
Isolate-20 presented the following measurements: Greater diameter, 3,69 (2,95-4,43) ${ }_{\mu} \mathrm{m}$. Lesser diameter with median $1,70(1,27-2,31)$ ${ }_{\mu} \mathrm{m}$; area with median $5,70(3,66-9,30){ }_{\mu} \mathrm{m}$. A statistical difference was observed regarding measurements of greater diameter and area between the strain $\mathrm{RH}$ and isolate 3 and similarity with isolates 15 and 20. Statistical analysis of lesser diameter in the three groups did not demonstrate significant variation.

We found that virulent isolates $(15,20$ and $\mathrm{RH}$ ) were smaller in length and area as compared 
10.18606/2318-1419/amazonia.sci.health.v6n1p48-53 Revista Amazônia Science \& Health.

2018 Jan/Mar
Silva MG, Ibrahim FM, Santos GJVG, Molina OF, Neto JB, Gontijo EEL, Castro AM.

Morphometric analysis and virulence of isolates of Toxoplasma gondii recovered from pregnant and newborn mice in Goiânia-GO, Brazil. with isolate-3. This observation reinforces the hypothesis that besides differences in behavior and genetic variations, morphological variations also exist among different strains of $T$. gondii and these findings have never been reported previously in the literature. However, as all any living organisms with intra-specific genetic variation, there is no morphological uniformity among individuals, and this may also be a rule in the case of Toxoplasma gondii ${ }^{11,20-22}$.

\section{FINAL CONSIDERATIONS}

This new morphometric parameter corroborates the presence of diversity among isolated strains and may constitute new information used to characterize and analyze those strains.

New strains are being isolated and the information from these ongoing studies will be used to complement findings from the current investigation.

\section{REFERENCES}

1. Câmara JT, Silva MG, Castro AM. Prevalência de toxoplasmose em gestantes atendidas em dois centros de referência em uma cidade do Nordeste, Brasil. Rev. Bras. Ginecol. e Obs. [Internet]. 2015;37:64-70. Available from: http://www.scielo.br/scielo.php?script=sci_arttext \&pid=S0100-

$72032015000200064 \& \operatorname{lng}=p t \& n r m=i s o \& t \operatorname{lng}=e n$

2. Maldonado YA, Read JS, On C, Diseases I. Diagnosis, Treatment, and Prevention of Congenital Toxoplasmosis in the United States. Am. Acad. Pediatr. 2017; 139(February):53.

3. Silva MG da, Vinaud MC, Castro AM de. Prevalence of toxoplasmosis in pregnant women and vertical transmission of Toxoplasma gondii in patients from basic units of health from Gurupi, Tocantins, Brazil, from 2012 to 2014. PLoS One [Internet]. 2015;10(11):e0141700. Available from: http://dx.plos.org/10.1371/journal.pone.0141700

4. Oliveira NN de. Caracterização funcional de cepas de T. gondii. Dissertação de Mestrado. Instituto de Ciências Biomédicas da Universidade de São Paulo. 2009.

5. Cruz IO. Toxoplasmose experimental no modelo murino com fenótipo extremo para tolerância oral: caracterização celular e humoral. Tese de Doutorado. Instituto Oswaldo Cruz. 2014.

6. Flausino W, Soares CO, Freire RB, Lopes CWG. Variações intraespecíficas de taquizoítos do Toxoplasma gondii (Apicomplexa: Toxoplasmatinae) isolados de uma infecção natural e comparadas frente a cepa congênita. Rev. Bras. Ciência Veterinárias. 1998;5(2):6367.

7. Oliveira PA, Oliveira FC, Faria LMJ, Cademartori $B G$, Marcolongo-Pereira C, Coelho ACB, et al. Patogenicidade e virulência de Toxoplasma gondii isolado de suínos de criação artesanal no sul do Brasil. Pesqui. Vet. Bras. 2014;34(12):1186-1190.

8. Sevá AP, Silva RC, Castro APB,Langoni $H$. Avaliação da virulência de cepas de Toxoplasma gondii, em camundongos, isoladas de cães com sinais neurológicos, em Botucatu, SP. Veterinária e Zootec. 2006;13(1):33-43.

9. Costa RC. Aspectos epidemiológicos e importância da toxoplasmose na sanidade animal e na saúde pública. Univ. Fed. Goiás Esc. Veterinária e Zootec. Programa Pós-Graduação em Ciência Anim. 2013; 36.

10. Yadav RK, Maity S, Saha S. A review on TORCH: groups of congenital infection during pregnancy. J. Sci. Innov. Res. [Internet]. 2014 [cited 2014 Jun 3];3(2):258-264. Available from: file:///D:/Usuários/Marcos/Downloads/A review on TORCH.pdf

11.Trevisan N. Genotipagem de isolados de toxoplasma gondii obtidos de Gallus gallus naturalmente infectados no estado de Santa Catarina. Univ. do Estado St. Catarina - UDESC Cent. Ciências Agroveterinárias - CAV Mestr. em Ciência Anim. 2013

12.Lopes AP, Dubey JP, Dardé M-L, Cardoso L. Epidemiological review of Toxoplasma gondii infection in humans and animals in Portugal. Parasitology [Internet]. 2014 Nov [cited 2014 Nov 18]; 141(13):1699-708. Available from: http://www.ncbi.nlm.nih.gov/pubmed/25215422

13.Dubey J. Toxoplasmosis of animals and humans. 2nd ed. New York: CRC Press; 2010.

14.Alvarenga FR. Valor do teste de avidez da igg como marcador de doença aguda ou crônica e de transmissão vertical na toxoplasmose [Internet]. 2009; Available from: http://posstrictosensu.iptsp.ufg.br/uploads/59/orig inal_FernandaRassi2009.pdf

15.Cristina $R$, Lima $M$. Relação entre másformações e óbitos fetais em decorrência de toxoplasmose congênita tratadas em uma clínica particular de Goiânia-GO. Ensaios e Ciência Ciências Biológicas, Agrárias e da Saúde. 2011;15(4):53-63. 
16. Rodrigues IM, Costa TL, Avelar JB, Amaral WN, Castro AM, Avelino MM. Assessment of laboratory methods used in the diagnosis of congenital toxoplasmosis after maternal treatment with spiramycin in pregnancy. BMC Infect. Dis. 2014;14(349).

17.Rodrigues IMX. Avaliação de componentes da resposta imunológica de recém-nascidos expostos intraútero ao Toxoplasma gondii Tese. Inst. Patol. Trop. e Saúde Pública da Univ. Fed. Goiás. 2013.

18.Sosa LN. Prevalencia de la infección toxoplásmica en mujeres en edad fertil de Córdoba - Argentina. Univ. Nac. Córdoba Fac. Ciencias Médicas Esc. Salud Pública Prevalencia. 2013.

19.Vaz RS, Rauli P, Mello RG, Cardoso MA. Toxoplasmose Congênita: Uma doença negligenciada? Atual política de saúde pública brasileira. F. Actions Sci. Reports. 2011;3(3):0-8.

20.Fialho CG, Teixeira MC, Araujo FAP de. Toxoplasmose animal no Brasil. Acta Sci. Vet. 2009;37(September 2008):1-23.

21.Freire CMV, Tedoldi CL. Hipertensão arterial na gestação. Arq. Bras. Cardiol. [Internet]. 2009 Dec [cited 2014 May 26];93(6):159-165. Available from:

http://www.scielo.br/pdf/abc/v93n6s1/v93n6s1a1

7.pdf

22.Gaete MIL. Associação entre uveíte posterior ativa presumivelmente por Toxoplasma gondii e $\lg$ A secretora específica na lágrima Maria. Univ. Fed. pernambuco cent. ciências da saúde Med. Trop. 2003. 